\title{
Public Governance Perspective to Adressing Development Problems in Surabaya
}

\author{
Irfan Murtadho' $^{1}$, Ali Roziqin ${ }^{2}$ \\ ${ }^{I}$ Department of Public Administration Diponegoro University, Tembalang, Semarang, Indonesia \\ ${ }^{2}$ Magister of Public Administration, Universitas Gadjah Mada, Jl. Prof Sardjito, Sekip, Yogyakarta, Indonesia \\ Irfan.murtadho@gmail.com and ali_roziqin@ymail.com,
}

Keywords: Public Governance, Development Problems, Surabaya.

\begin{abstract}
Surabaya is the second largest metropolitan area in Indonesia after Jakarta. This city has become the destination of urbanization and industrial centre in the eastern part of Indonesia. As a big city, Surabaya certainly has complex problems as usually faced by common big cities in Indonesia, such as traffic jam, pollution, social gap, poverty, public services, and waste management and environmental problem. The purpose of this paper is to review which one is the best practice to address the development problems with public governance perspective in Surabaya. The author used a qualitative approach by collecting literature review and secondary data. The author found that Surabaya government has partnered with partners to solve the problem of urban development either from the public sector, private or non-profit organizations. This is an effort to improve public services and welfare of urban communities, which is expected to be a solution for other local governments in addressing the problems of regional development.
\end{abstract}

\section{INTRODUCTION}

The development of the world demands for the study of public administration to continue to grow. As the basic science to the community, it would be very dynamic against the existing developments in society. Charles Darwin once said in his theory of evolution that "the lasting is not the strongest but those who can best manage change". The concept seems to also be in the scope of public administration. The public administration (state) was born in the nineteenth century when the attention of the academic community directed in observing the business of the state.

The government which is used to be the centre of administration gradually changed into public governance. It is not surprising, therefore, that the first paradigm to state the administrative political dichotomy of the separation of political functions and administrative functions (Frank J, 1990) is considered very pragmatic for modernists.

Political dichotomy of administration included in the old paradigm (Old Public Administration) is famous for the hierarchical system and rule of law. Then comes the new paradigm of NPM (New Public Management) which is substantially trying to apply the principles of private into the system of public organization. Currently, the paradigm is NPS (New Public Services) (Denhardt, 2000) or public governance (Dwiyanto, 2002; Bovaird T \& Loffler, 2009) or collaborative governance (A Gash \& Ansell, 2007). Whatever the term in outlining this paradigm refers to the role of all stakeholders in the community, regarding society as the subject of policy not the object of policy, consensus and democratic citizenship and public-private collaborative.

Indonesia is a democratic country upholding democratic values such as transparency and participation. Therefore, in its role, society will play more role in the process of the nation and the state. However, in the public services delivery, the orientation of power the bureaucracy in Indonesia has become increasingly distant with its mission (Dwiyanto, 2002). Monopoly of authority owned by the government has eroded the public interest orientation. The bargaining power of the community is quite low when confronted with the power of government or bureaucracy. Symbols such as "single 
ruler, national stability and state interest, and development" have become the basis of criteria in government and public service delivery. The value of humanism and fairness, and freedom lack a central place in bureaucratic life. Therefore, the new paradigm (NPS/Public Governance/Collaborative Governance) is expected to empower the community and all of the stakeholders to participate in every process of public administration system.

In globalization era, the future role of government is not only as the single agent in solving public problems. Some public policy analysts said that there are other stakeholders within a country or even beyond the borders of the country that will create a new world (Reich, 1991; Farazmand, 1999). This is certainly a challenge as well as opportunities, especially for local government to advance the region. Problems in this era of globalization will be increasingly complex. Bureaucracy as a "machine of country" also needs to make an updates and innovations for the changes that occur in society. The public bureaucracy should involve their civil society actively in the development program of the country (Weidner, 1970; Firdaus, 2016). The role and participation of the people in the future will also be very urgent in the development process.

In reform era, government has changed from a centralized system to decentralization. Decentralization provides an opportunity for the region to be more developed and self-sufficient in accordance with its potential. The government only provides "guidance" to the regions. The implication is a change in the pattern of relations between the central government and local government (Pratikno, 2007). Decentralization is considered to be important, given there are many districts, municipalities and provinces which have different problems according to the characteristics of the region (Keban, 2007). Not only that, but decentralization will also change the pattern of internal relationships which exist in areas such as the private sector and local community.

The research focused on Surabaya as the case study. The population in Surabaya per-2012 were $3,006,789$ inhabitants by producing 2,913, 18 tons of waste in one day (Surabaya.go.id). The number of units or equipment that operate every day are 46 compactors and 30 dump trucks. It means, one person in Surabaya produces $1 \mathrm{~kg}$ of garbage every single day (Office of Population Service \& Civil Registration and Office of Sanitation \& Green Open Space (DKRTH) Surabaya, 2017). Data released by Surabaya Sanitation and Gardening Agency (DKP), in 2014 and 2015 recorded there were 1,400 tons of garbage per day produced by the people of Surabaya and thrown to Benowo Disposal Place (TPA). This number has increased from 2011 to 2013.

Another problem in Surabaya is pollution. As an industrial city, Surabaya cannot be separated from pollution problem. The problem of pollution in Surabaya is even categorized quite severe. Dewi J Putriatni as the Head of Environmental Agency (BLH) of East Java Province stated that pollution in Surabaya was ranked in the third worst pollution in Asia after Bangkok and Jakarta. The pollution index (IPU) in Surabaya itself has reached 84.49 in 2014.

Such rapid urban development also has negative consequences on various aspects including environmental aspect (Ridho, 2011). Most of the lands especially in the centre of the city are covered by roads. Buildings in Surabaya mostly have very different characteristics with the green open space which can absorb the droplets of rain, minimize flooding in the city and absorb carbon dioxide $(\mathrm{CO} 2)$ resulted from the vehicle pollution. The volume of vehicles which continuously increasing also cause congestion everywhere. It is getting worse with a poor transport system (Aloisius, 2015). Consequently, people prefer using personal transportation rather than public ones.

The complexity of urban development must be followed by different bureaucratic responses and ways of thinking. To achieve goals and solve the existing problems, all of the stakeholders must jointly address the public issues. Therefore, the author in this paper tried to describe how to solve the development problems in Surabaya within the framework of Public Governance.

\section{METHODS}

The authors used a literature review in this paper. Literature review is a critical and in-depth evaluation of previous research, a summary and synopsis of a particular area of research, allowing anybody who read the paper to establish why one is pursuing a particular topic (Shuttleworth, 2009). It is considered as an explanation and a review to the role of stakeholders in addressing the development problems of Surabaya. The authors collected the data from previous research about the development of Surabaya, public governance, collaborative governance, and many other relevant sources. Meanwhile, the authors also obtained other information from news, website, legal document, and etc. Furthermore, the authors analysed both data between the fact in field and concept from literature 
review, which will be described in the following chapter, result and discussion.

\section{RESULTS AND DISCUSSIONS}

\subsection{Surabaya}

Surabaya is one of the metropolitan cities in Indonesia apart from Medan, Jakarta, Bandung, and Makassar. Surabaya is the capital of East Java province. Surabaya is a major growth centre in eastern Indonesia, due to strong manufacturing and agricultural business to produce export products. The Port of Surabaya is the hub of entry between East and West Indonesia, as well as for eastern and international Indonesian trading partners (Rismaharini, 2007).

The growth of population in Surabaya continues to increase, recorded in 2007 the population was 2,861,928, then in 2012 became 3,006,789 inhabitants (Surabaya.go.id). Population growth cannot be separated from the flow of urbanization, and urban development process is growing. The increasing population number indirectly increases social problems. Thus, the role of government will become more difficult in the future. Therefore, to solve problems, the Government of Surabaya needs to build partnerships with other stakeholders or increase the society participation.

\subsection{Public Governance}

\subsubsection{Public Private Partnership}

The concept of partnership between the government and the private sector is inevitable as part of solving problem. Each of the two sectors recognizes that they have limited capacity. Thus, the collaboration in partnership form is considered as an effective step for stakeholders. The change in government to be more open resulting a partnership concept involving the private sector in the development program. The concept of this partnership has been contained in Presidential Regulation No. 13 of 2010 on publicprivate partnership (PPP).

Public Private Partnership is closely linked to the term of social consensus which emphasizes the view on a certain service that should be available to all citizens regardless of their income and what kind of services they provide (Dwi Purwanti, 2016). There are distinctive characteristics that can differentiate between PPP and the other cooperation, as presented by Lienhard (Dwiyanto, 2011):

1. Partnership involves at least one government agency and one private institution.

2. Partnership is made to achieve mutual goals or mutually compatible and complementary.

3. It is complex and requires intensive coordination

4. Partnership is conducted in order to conduct procurement or implementation of certain tasks.

5. Has a long-term orientation

6. The unification, utilization and synergy of government and private resources.

The partnership that Surabaya's government took, for example is in overcoming waste problem in. Waste problems are the common problem for the urban life. In this case, Surabaya Government established partnership with PT. Sumber Organik in 2013 with cost reaching 52 billion Rupiahs and rose in 2014 to 62 billion Rupiahs (Tempo, 2017). The purpose of this partnership is to reduce the volume of waste in LPA Benowo and to process waste to be something more useful for the community. For example, waste changed into electricity.

On the other hand, to support this partnership with other organizations, Surabaya's government uses ICT (Information and Communication Technology) approach through e-procurement and eproject. These tools are more transparent and accountable.

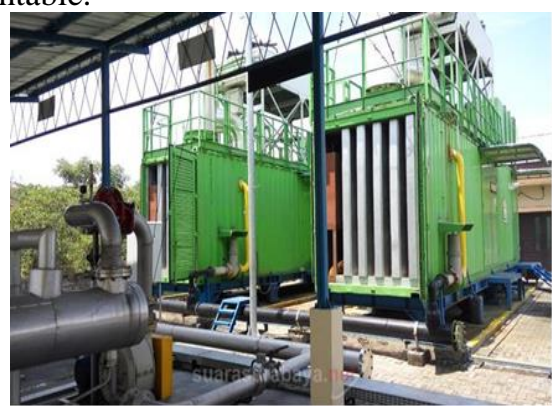

Figure 1. One of waste processing machine on LPA Benowo, Surabaya

Source: suarasurabaya.net

Another example of partnership between Surabaya's government with private sector is the development of green open space in form a city park, the garden of Undaan. Taman Buah Undaan formerly used by public refuelling station in green lane, but it has been revitalized into garden (Hendratna, 2011). 
The partnership of RTH development of the park is in line with the government's development. The government involvement in the construction of facilities and infrastructures are decreasing. In this case, the government is likely act as a facilitator who bridges the relationship between the society and the private sector. The government cannot do all the works because of the limited funds and human resources, thus a cooperation and partnership with other parties must be done in order of the quality of public services in accordance with the society's demands (Paskarina, 2007).

\subsubsection{Public-Citizen Partnership}

In the public governance paradigm, orientation is about the public or society. Previously, the communities were act as an object for the public policy groups. In this case, community is more involved in all decision-making process. EMusrenbang is a site to accommodate the idea of Surabaya's people and to track the issue. One of the examples is to resolve the environmental issues. The emergence of e-musrenbang is marked by many problems regarding the number of proposals entered in printed form (hard copy), the recapitulation process, and the budget given is not on target (Kurniawati, 2016).

The influence of e-musrenbang also affected the handling of environmental problems, such as people empowerment.

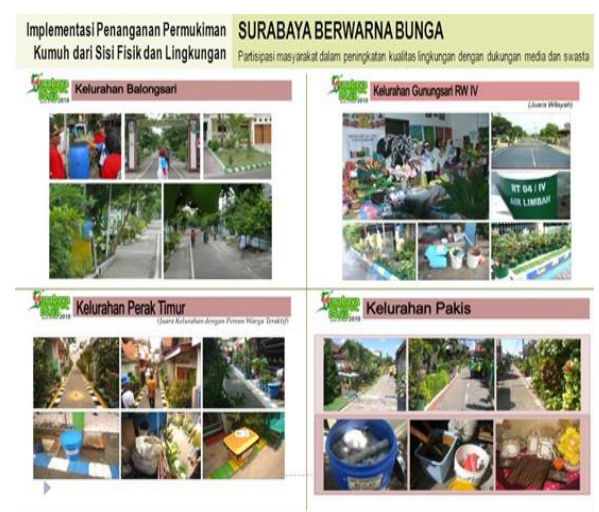

Figure 2. One of the green and clean settlement.

Source: Surabaya.go.id

Community involvement is one of the keys to the success of a policy. Therefore, a policy will succeed if coupled with a good level of community participation. The same thing can be seen in the management of mangrove forests on the north coast of Surabaya. As explained in Maria's research, although constrained by budget (Maria Jose, 2014).

\subsubsection{Public International Organizational Partnership}

In the past era, only the central government is actively cooperating with NGOs or international institutions. However, in the era of globalization and openness, it is possible for governments or regional institutions to engage in international cooperation. This is supported by the existence of regional autonomy that gives freedom in advancing the region. Partnership that the Surabaya's government did substantially has two models, for smart city and sister city.

Surabaya continues to develop its area as a city that becomes a trendsetter for other regions. Innovation continues to be done, for example is establishing international cooperation. One of the partners in sister city cooperation in Surabaya is Kitakyushu in Japan. Kitakyushu is an industrial city which also experienced environmental problems such as factory waste and air pollution. But with government efforts, community participation and technological development, Kitakyushu is able to address their city's problems. Actually, the cooperation between Surabaya and Kitakyushu started in 1997, focusing on waste management. At that time, the cooperation began with the signing of the Joint Declaration of The Kitakyushu Conference on Environmental Cooperation among the Cities in the Asian Region. However, in the early years of cooperation, it did not develop rapidly during the period of 1998 to 2006. In 2007, the City Government of Kitakyushu gave assistance to the Surabaya's Government to support the implementation of the Kalimas Revitalization Program which included two things: water quality improvement and community participation development. Until 2012, the two cities agreed to strengthen their sister city cooperation in a $\mathrm{MoU}$ (Monalisa, 2017).

Surabaya and Kitakyushu have four green sister city partnership projects aimed at making Surabaya cleaner and reducing the amount of waste in Surabaya. Super Depo Sutorejo is one of the results of partnership between the Japanese and the Government of Surabaya. Super Depo Suterejo is one of the garbage facilities in Surabaya to be able to reduce the volume of waste to Final Disposal Site (TPA) and create the low-carbon society by separating the dry waste and organic waste where 
the dry waste will be recycled and organic waste will made as compost. The Japanese side provides assistances to the Surabaya Government in the form of buildings and equipment, and the Surabaya is enough to prepare the place and its workforce.

Even, lately the city government is cooperating with Liverpool in the development of the port city (maritime) and the creative economy. As Gery Billion (Liverpool Mayor) said "There are 5 agreements that are generated in cooperation in the field of port and maritime management, economy, human resources and capacity building, smart cities and creative industries" (Detik.com, 2017). This cooperation is expected to bring goodwill for both cities, specifically in urban development and development.

\section{CONCLUSIONS}

The practice of public governance or collaborative governance in overcoming the development problems in Surabaya has provided another alternative for stakeholders. Partnership among stakeholders were successful enough to overcome the problem of waste, green open space, urban development, and to improve public services. Accordingly, Surabaya is often used as a place for benchmarking by other regional governments. Apart from that, there are some obstacles such as the size of the government's role. Thus, according to the authors' opinion, the government applies top-down system. Therefore, in the future, the quality of community involvement should be encouraged more effectively, one of them is by increasing the capacity of the community such as education and community self-sufficiency in economy (Small and Medium Enterprise). Therefore, the stakeholders should have a balanced role with each other in determining the direction of development and local policy.

The best practices of public governance or collaborative governance implemented in Surabaya need to be adopted by other regions in Indonesia as an innovation effort in developing the region.

\section{REFERENCES}

Ansell dan Gash. 2007. Collaborative Governance in Theory and Practice, Journal of Public Administration Research and Theory. Publised by Oxford University Press.

Bovaird, T \& Loffler, E. 2009. Public Management and Governance. London:Routledge.
Farazmand, Ali. 1999. Globalization and Public Administartion. Florida Atlantic University Press

Firdaus. 2016. Sound Governance in Case of Mamminasata Metropolitan Development Area in South Sulwesi Province. JKAP. Vol. 20 No. 1-May 2016 p1-22.

Denhardt and Denhardt. 2007. The New Public Service, Expand Expanded Edition: Serving Not Steering. New York: Greenwood Press.

De Rozari, Aloisius dan Wibowo, Yudi Hari. 2015. Faktor-Faktor yang menyebabkan kemacetan Lalu Lintas Utama Kota Surabaya. Jounal Untag Surabaya.

Dwiyanto, Agus. 2012. Reorientasi Ilmu Administrasi Publik dari Government ke Governance. Yogyakarta: Gadjah Mada University Press.

Dwiyanto, Agus. 2011. Manajemen Pelayanan Publik: Peduli, inklusif, dan Kolaboratif. Yogyakarta: Gadjah Mada University Press.

Dwiyanto, Agus. 2012. Reformasi Birokrasi Publik di Indonesia. Yogyakarta. Gadjah Mada University Press.

Goodnow, Frank. J. 1900. Politics and Administration: A study in Government. Columbia University.

Hendratna, Ridho Akhir. 2011. Kemitraan Pemerintah dan Swasta Dalam Pembangunan Ruang Terbuka Hijau di Surabaya (Studi Kasus Taman Buah Undaan). Ejournal Unesa Surabaya.

Ismail, Suhaiza. 2013. Critical Succes Factors of Public Private Partnership (PPP) Implementation in Malaysia. Asia-Pacific Journal of Bussines Administration Vol. 5 No. Emerald Group Limited 1757-4323.

Keban, Yeremias T. 2007. Membangun Kerjasama Antar Pemerintah Daerah Dalam Era Otonomi. Jurnal Ilmu Pemerintahan Indonesia. Jakarta.

Kurniawati, Reny Dwi. 2016. Efektivitsd Sistem Electronic Musyawarah Rencana Pembangunan (EMusrenbang) di Kecamatan Tambaksari Kota Surabaya

Maria Jose, Da Consiecao Freitas. 2014. Kemitraan Pemerintah dan Masyarakat Lokal dalam Pengelolaan Hutan Mangrove di Pantai Utara Kota Surabaya. JKMP, Vol. 2, No.103-220

Octavia, Monalisa Bonieta. 2017. Kerjasama Green Sister City Surabaya dan Kitayushu (Studi Kasus Pengelolaan Sampah) Melalui Super Depo Suterejo. E-journal Ilmu Hubungan Internasional. ISSN $2447-$ 2623.

Paskarina, Caroline. 2007. Kemitraan Pemerintah dan Swasta. Badan Perencanaan dan Pembangunan daerah Cianjur.

Pratikno. 2007. Kerjasama Antar Daerah: Kompleksitas dan Tawaran Format Kelembagaan. Program S2 PLOD. UGM. Yogyakarta.

Sangkala. 2011. Praktek Good Governance dan Implikasinya terhadap Konsep dan Ideologi Penyelenggaraan Pemerintahan dan Administrasi di negara-negara berkembang (Sound Governance Sebagai Antitesis Dari Good Governance). Jurnal Ilmu Administrasi Vol. 1 No. 1 Juni 2011 
Tri, Rismaharini. 2007. Pengembangan Infrastruktur Kota Surabaya antara problem dan solusi. Paper Keynote Speaker.

Purwanti, Nurul Dwi. 2016. Collaborative Governance (Kebijakan Publik dan Pemerintahan Kolaboratif). Yogyakarta: Gava Media.

Reich, R.B. (1991). The Work of Nations: Preparingfor 21st-Century Capitalism. New York: Simon \& Schuster.

Sangkala. 2011. Praktek Good Governance dan Implikasinya terhadap Konsep dan Ideologi Penyelenggaraan Pemerintahan dan Administrasi di negara-negara berkembang (Sound Governance Sebagai Antitesis Dari Good Governance). Jurnal Ilmu Administrasi Vol. 1 No. 1 Juni 2011.

Syafri, Wirman. 2012. Studi Tentang Administrasi Publik. Jakarta: Erlangga

Weidner, Edward W. 1970. Development and Innovational Roles, in Weidner(ed.), De-velopment Administration in Asia. Durham: Duke University Press.

http://www.abouturban.com/2016/08/04/surabaya-kotadengan-masalah-sampah-dan-polusi-yang-masihperlu-perhatian-khusus/

https://news.detik.com/berita-jawa-timur/d3745329/surabaya-dan-liverpool-resmi-jadi-sister-city https://nasional.tempo.co/read/517117/pengelolaansampah-di-surabaya-libatkan-swasta 